\title{
Analysis Of Characteristics Of Waste Based On Extraction Time Variations (Corn Variety Pioneer)
}

\author{
S. Rosalinda ${ }^{1}$, Sarifah Nurjanah ${ }^{1}$, Rudy Adi Saputra ${ }^{2}$, Gatot Yuduko ${ }^{3}$, Asri \\ Widyasanti $^{4}$, Nurpilihan Bafdal ${ }^{4}$ \\ \{rosalinda.chandrady@yahoo.co.id ${ }^{1}$, sarifahnurjanah@gmail.com², \\ nurpilihanbafdal@yahoo.com ${ }^{5}$ )
}

Departement of Agricultural and Biosystem Engineering ${ }^{145}$, Department of Food Technology Faculty of Agro-Industrial Technology Faculty of Agro-Industrial Technology ${ }^{2}$, Padjadjaran University, Bandung, School of Business and Management Bandung Institute of Technology ${ }^{3}$, Indonesia Sumedang km 21, Jatinangor, Bandung 40600

\begin{abstract}
Corn starch waste has enormous potential to be used as food, feed ingredients and fiber industry. The study examined the chmical composition characteristics of Pioneer variety corn starch waste based on the extraction time variations carried out in the laboratory. The study was conducted with an experimental method consisting of 4 treatments namely time variables (1x24 hours; $2 \times 24$ hours; $3 \times 24$ hours; 4x24 hours) were repeated 3 times. Responses observed in epidermis waste (water content, ash content, cellulose content, hemicellulose content, lignin content and yield), and yellow slurry waste (carbohydrate content, starch content, fat content, protein content, water content, ash content and yield). The results showed the variation of time $2 \times 24$ hours produced the highest levels of starch with waste content in the epidermis as follows: water content $=5.45 \pm 0.023$, ash content $=0.21 \pm 0.046$ hemicellulose levels $=56.57 \pm 0.621$; cellulose content $=21.26 \pm 0.231$; lignin content $=2.82 \pm 0.352$, yield $=20.02 \pm 0.02$ while in yelow slurry waste yields water content $=$ $7.69 \pm 0.002$, ash content $=0.33 \pm 0.021$; protein content $=3.80 \pm 0.612$; fat content $=$ $11.85 \pm 0.142$; carbohydrate levels (by difference) $=76.33 \%$; starch content $=63.30 \pm$ 0.231 and yield $=44.02 \pm 0.02$. The findings show that epidermis and solid waste has a good chemical composition used as feed ingredients, feed ingredients and various downstream industries of the fiber industry.
\end{abstract}

Keywords: Pioneer, Extraction Time, Epidermis Waste, Yellow Slurry Waste 


\section{Introduction}

Corn seeds have many benefits such as food, food, the pharmaceutical industry, cosmetics, the adhesive industry, and can also be used as a source of bioenergy. Utilization of corn is currently mostly used as feed raw materials both for the feed industry and independent breeders. Utilization of corn as animal feed has increased from year to year. The use of corn as animal feed in 2014 to 2016 increased from 11.21 million tons in 2014 to 12.06 million tons in 2015 and 12.27 million tons in 2016. The use of corn as food is ranked second after feed and increasing from year to year. The use of corn as food in 2014 amounted to 4.13 million tons and increased to 4.34 million tons in 2015 and 5.15 million tons in 2016 [1]

Indonesia is a country whose population consumes carbohydrates as a staple food. Carbohydrate-producing plants include corn. corn in its chemical composition has the highest carbohydrate content compared to other compositions. Research on corn starch that has been carried out, among others, by [2] uses 11 varieties of raw materials; Pulut Takalar, Pulut Gorontalo, Prospective Pulut, Local Takalar, Palakka, Krisna, Bisma, Lamuru, Anoman-1, Srikandi Putih-1, and Srikandi Kuning-1. The parameters analyzed were: starch yield, starch content, fineness level ( 80 mesh), $\mathrm{pH}$, specific gravity, white degree, ash content, protein content, fat content and fiber content. Corn is produced into starch to produce waste. This byproduct waste has several forms of waste including epidermis waste and yellow slurry waste. This research analyzes the starch waste content. The results of this study produce contents that can be utilized for industry.

\section{Methods}

\subsection{Raw Material}

Pioneer variety from the farmer group of Lempong Village, Sukaharja Village, Banyuresmi District, Garut Regency. Chemicals: $\mathrm{Na}_{2} \mathrm{~S}_{2} \mathrm{O}_{3}$, aguades, materials for analyzing parameters of carbohydrate content, starch content, fat content, protein content, moisture content, ash content and yield. Analysis of research parameters based on Standard SNI01 2891 1992 testing of food and beverage ingredients) and Chesson 1981. Figure 1 shows the pioneer corn kernels. 


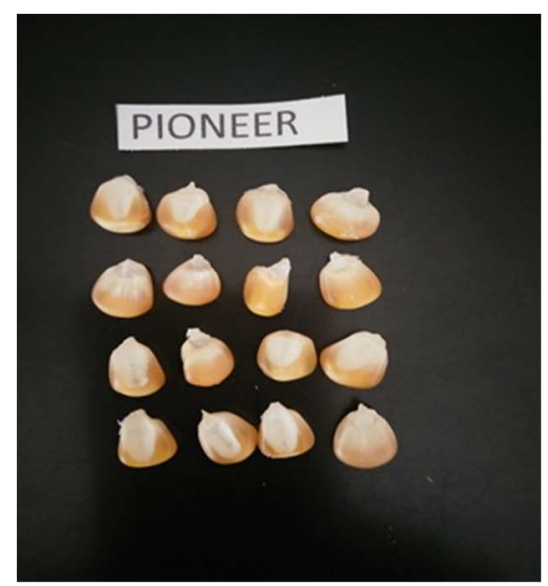

Figure 1. Row Material Varieties of Pioneer

\subsection{Equipment}

Sieve, basin, plastic sieve, filter cloth, baking sheet, spatula, aluminum foil, $1000 \mathrm{ml}$ and $100 \mathrm{ml}$ measuring cup, $1500 \mathrm{ml}$ glass beaker, blender, Waterbatch, centrifuge, vacuum oven, tyler sieve.

\subsection{Procedure for making starch:}

Preparation as raw material before extracting based on the extraction time is treated with a water content of 14\% (Koswara, 2009). His research carried out the extraction process in producing starch. Broadly speaking, the research procedures are as follows: (1) Sorting up to obtain whole free corn kernels from broken corn and unwanted objects; (2) carry out weighing with the desired weight on controlled water content ( $\pm 14 \%$ ); (3) washing corn seeds; (4) Measuring distilled water to the desired liter size and adding $0.2 \%$ (b / v) $\mathrm{Na}_{2} \mathrm{~S}_{2} \mathrm{O}_{5}$; (5) Corn soaked with a mixture solution of aguades and $\mathrm{Na}_{2} \mathrm{~S}_{2} \mathrm{O}_{5}$ until the corn is submerged; (6) do extraction process in waterbath with control of extraction temperature between $60-62{ }^{\circ} \mathrm{C}$ and various variations of extraction time 1x24 hours, 2x24 hours, 3x24 hours, 4x24 hours (each triplo); (7) After the extraction time is reached, do the corn washing process; (8) Blend the washed corn with a grinder with the same speed and time counter in all time variation treatments; (9) do the filtering process to obtain starch, yellow slurry, and starch solution; (10) Perform a deposition process for 24 hours; (11) Perform a centrifuge process with the same speed and capacity in all treatment variations in extraction time up to 1 repetition of washing obtained by the layer of starch and residual layer of starch; (12) Next to do the drying process 
with a vacuum oven at $62^{\circ} \mathrm{C}$ for 16 hours in all treatment variations in extraction time (14) do the sieve process on 100 mesh until white starch is obtained.

\subsection{Flow Diagram}

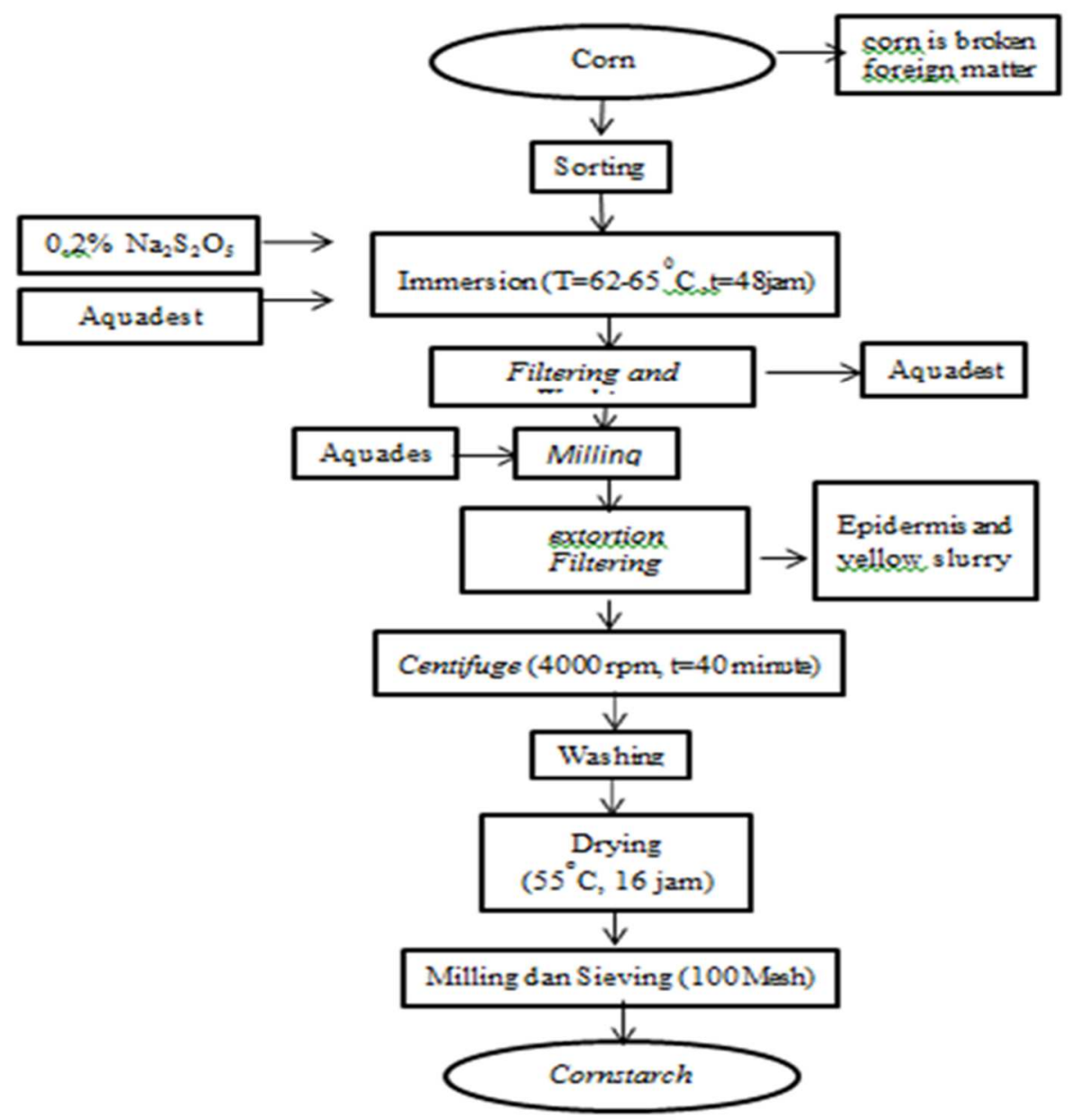

Figure 2. Flow Diagram Production Corn Starch 


\subsection{Research methods}

This research was conducted in postharvest engineering laboratories and engineering in the field of processing technology at the Padjadjaran University agricultural industry. This research aims to analyze the composition of waste starch. The research method uses laboratory research methods using descriptive. The independent variables in this study are time

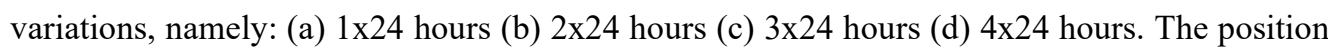
of the revised waste is waste from the grinding process, namely: epidermal corn and yellow slurry. This study two steps were carried out, namely (1) Analysis of the characteristics of epidermis waste observed by cellulose content parameters with method Chesson hemicellulose content and lignin levels (content and yield while the corn waste parameters were: cellulose content, hemicellulose content, lignin content and yield. (2) Analysis of the characteristics of Yellow slurry observed by parameters: moisture content [3], ash content [3], protein content [3], fat content[4] carbohydrate level (by difference), starch content (Luff Schrool), and yield.

\section{Results And Discussion}

\subsection{Characteristics of raw materials}

Characteristics of raw materials were analyzed including parameters: water content, ash content, protein content, fat content, carbohydrate content, starch content and yield. The results of the analysis of the parameters of pioneer variety and corn seed parameter data according to Be Miller, et al [5] can be seen in Table 1.

Table 1. Characteristics of Raw Materials and BeMiller Corn

\begin{tabular}{ccc}
\hline Parameter & $\begin{array}{c}\mathbf{A}^{*} \\
\mathbf{( \% )}\end{array}$ & $\begin{array}{c}\mathbf{B}^{*} \\
\text { Avarage (\%) }\end{array}$ \\
\hline Moister (\%,Wet) basis) & $10,17 \pm 0,053$ & 16.7 \\
Ash (\%) & $0,65 \pm 0.581$ & 1.42 \\
Protein (\%) & $6,64 \pm 1,234$ & 9.91 \\
Fat (\%) & $4,57 \pm 0,501$ & 4.45 \\
Karbohydrate (\%,by difference) & 78,87 & 67.52 \\
Starch (\%) & $75,49 \pm 0.352$ & 71.3 \\
\hline
\end{tabular}

resource: $A^{*}=$ Observation result. $B^{*}=$ BeMiller, et all (1996) [6].

He purpose of analyzing the parameters of raw materials is: look at the difference between corn kernels and BeMiller corn kernels and then see whether there is a change in 
parameter analysis before and after the starch extraction process based on extraction time. The observations showed that carbohydrate content, starch content, fat content of pioneer corn varieties were higher than corn seeds [5] whereas the Be Miller protein content was higher. Variations in water content and ash content due to differences in the anatomy of corn consisting of several layers with different percentages of each variety and the treatment after corn is harvested.

\subsection{Characteristics of epidermis}

He results of observations of epidermis waste at various extraction times can be seen in Table 2 which shows the following results: the percentage of water content and standard deviation ranges from $5.25 \% \pm 0.023$ at $1 \mathrm{X} 24$ hours to $6.57 \% \pm 0.854$ at $4 \mathrm{X} 24$ hours. Water content increases with the longer extraction time. The long extraction time causes the epidermis to expand more and more water content. Ash content indicates a condition where the more water content, the more ash content. Lignin levels and hemicellulose levels decrease while cellulose levels increase with longer extraction times according to Stasse and Wolthuis (1981) fiber contained in food can increase and decrease due to the long heating process which involves browning or Maillard reaction between protein and sugar degradation[7].

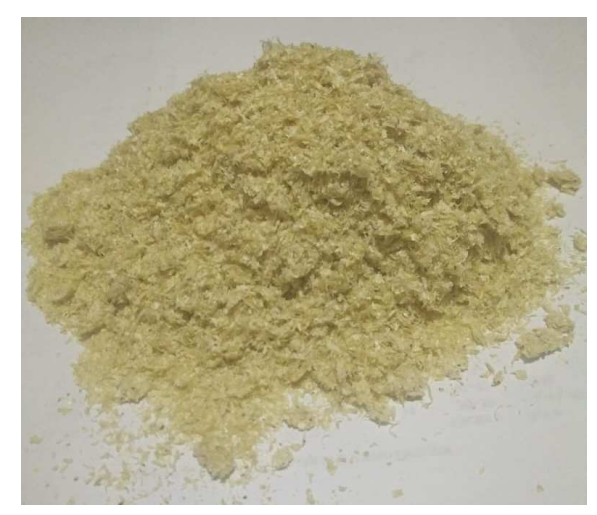

Figure 3. Waste Epidermis

The fiber content is very useful for the food industry and the pharmaceutical industry. This study produced a high hemicellulose content. High hemicellulose content can be used as a raw material for making xylitol which is useful as a raw material for toothpaste. 
Tabel 2. Hasil Analisa Parameter Kulit Ari Terhadap Variasis Waktu

\begin{tabular}{lccccc}
\hline \multicolumn{1}{c}{ Parameter } & $\mathbf{1 X 2 4}$ & $\mathbf{2 X 2 4}$ & $\mathbf{3 X 2 4}$ & $\mathbf{4 X 2 4}$ \\
\hline Moister (\%,Wet) & $5.25 \pm 0.854$ & $5.45 \pm 0.023$ & $6.34 \pm 0.324$ & $6.57 \pm 0.823$ \\
Ash (\%) & $0.18 \pm 0.769$ & $0.21 \pm 0.046$ & $1.23 \pm 0.546$ & $0.3 \pm 0.758$ \\
Hemicellulose (\%) & $60.67 \pm 0.835$ & $56.57 \pm 0.621$ & $51.45 \pm 0.923$ & $48.78 \pm 0.237$ \\
cellulose (\%) & $20.89 \pm 0.345$ & 21.26 & \pm 0.231 & $12.97 \pm 0.765$ & $24.23 \pm 0.967$ \\
Lignin (\%) & $3.89 \pm 0.345$ & 2.82 & \pm 0.352 & $2.56 \pm 0.876$ & $2.45 \pm 0.763$ \\
yield (\%) & $24.34 \pm 0.456$ & 20.02 & \pm 0.02 & $22.34 \pm 0.823$ & $25.32 \pm 0.693$ \\
\hline
\end{tabular}

The fiber content is very useful for the food industry and the pharmaceutical industry. This study produced a high hemicellulose content. High hemicellulose content can be used as a raw material for making xylitol which is useful as a raw material for toothpaste.

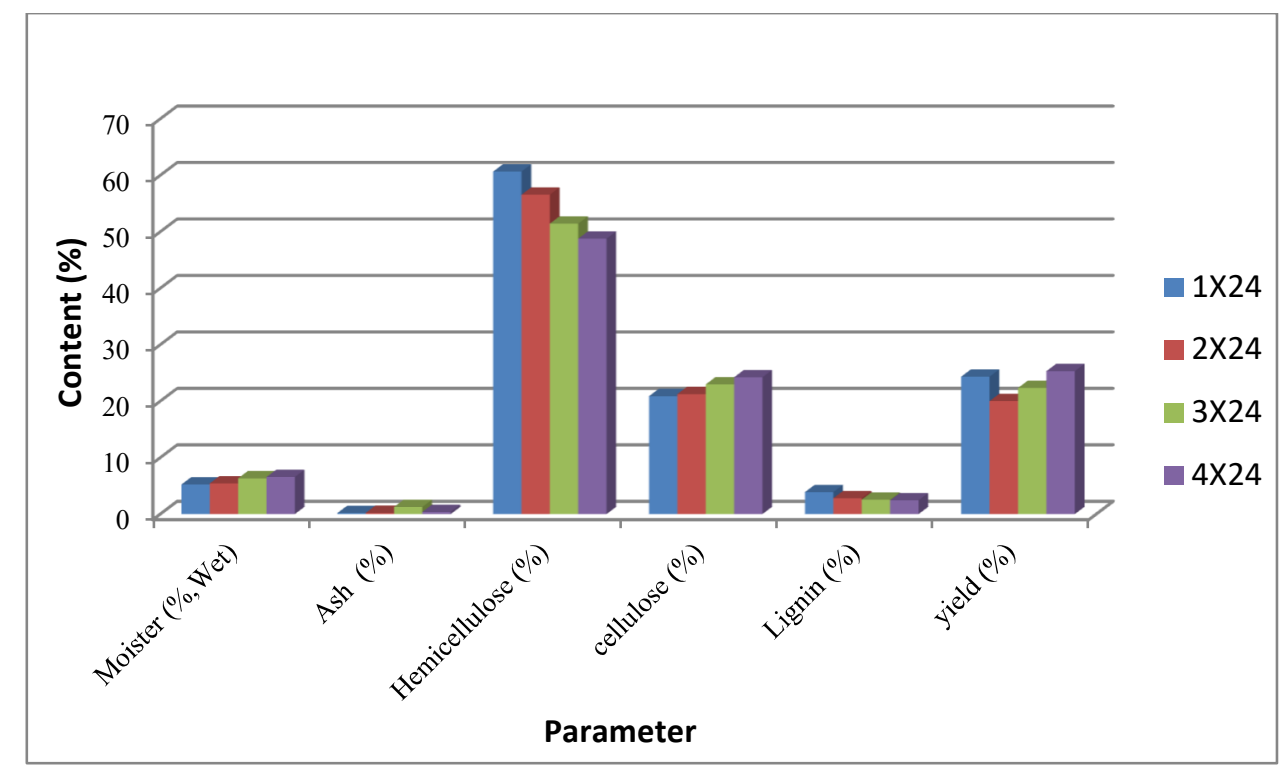

Figure 4. Parameter dan Content Epidermis 
he epidermis can be utilized including in the fields of pharmacy, animal feed, and home industries. The yield of epidermis is quite large at around $25.32 \%$. Reuse of this waste will add value to starch production.

\subsection{Characteristics of yellow slurry waste}

Observation results from yellow slurry waste there are several parameters consisting of water content, ash content, protein content, fat content, starch content. This content is analyzed as an alternative to yellow slurry waste reuse. Figure 5 (a) is yellow slurry waste and 5 (b) corn starch is produced.

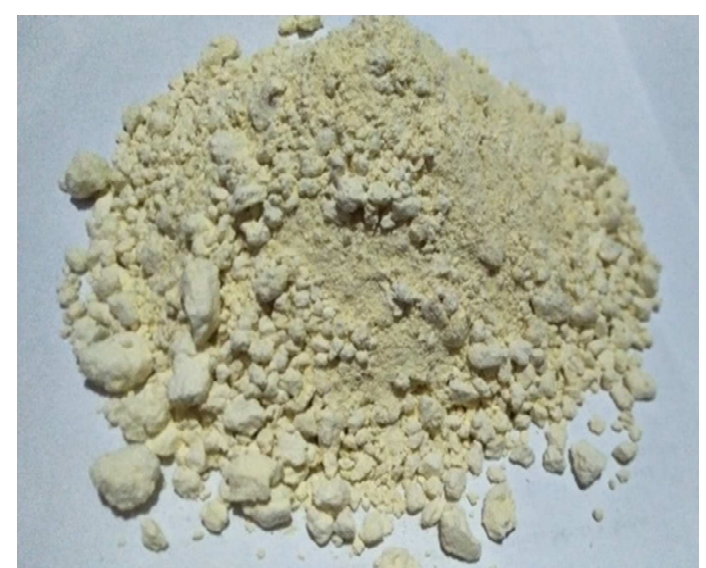

(a)

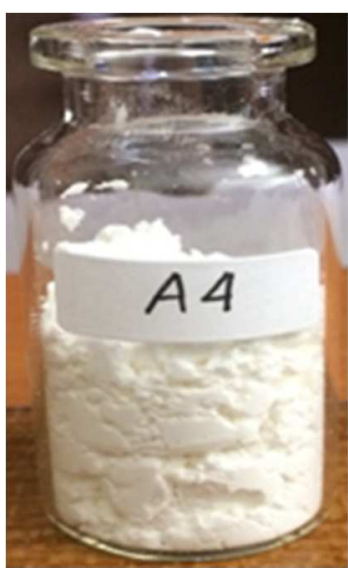

(b)

Figure 5. (a) Yeloow Slurry Waste, (b) Corn Starch

Figure 5 shows that there are differences in color from starch and yellow slurry waste. The composition of yellow slurry can be seen in Table 3 . 
Table 3. Results of Analysis of Yellow Slurry Waste Parameters vs Time Variations

\begin{tabular}{lcccc}
\hline \multicolumn{1}{c}{ Parameter } & $\mathbf{1 X 2 4}$ & $\mathbf{2 X 2 4}$ & $\mathbf{3 X 2 4}$ & $\mathbf{4 X 2 4}$ \\
\hline Moister (\%,Wet) & $8.31 \pm 0.321$ & $7.92 \pm 0.002$ & $7.42 \pm 0.015$ & $7.69 \pm 0.876$ \\
Ash (\%) & $0.16 \pm 0.224$ & $0.18 \pm 0.021$ & $0.48 \pm 0.024$ & $0.33 \pm 0.657$ \\
Protein (\%) & $0.32 \pm 0.645$ & $0.42 \pm 0.612$ & $3.64 \pm 0.823$ & $3.81 \pm 0.567$ \\
Fat (\%) & $1.21 \pm 0.432$ & $1.86 \pm 0.142$ & $12.23 \pm 0.248$ & $11.85 \pm 0.116$ \\
Karbohydrate(\%,by & 88.00 & 94.11 & 76.23 & 76.33 \\
difference) & & & & \\
Starch (\%) & $71.09 \pm 0.224$ & $78.80 \pm 0.231$ & $61.93 \pm 0.231$ & $63.30 \pm 0.456$ \\
yield (\%) & $35.22 \pm 0.543$ & $41.02 \pm 0.027$ & $42.02 \pm 0.024$ & $43.97 \pm 0.764$ \\
\hline
\end{tabular}

Table 3 shows the water content which decreases with increasing extraction time but instead the ash content increases. This relationship can be explained by the lack of water content in the material content to accelerate the evaporation process in the cavity of the material. This incident caused ash levels to increase. Protein levels, fat and carbohydrate levels increase with increasing time extraction time. The extraction time of 1 X24 hours and 2 X4 hours of increase in protein, fat and carbohydrate levels showed a significant increase but the increase from the 2 X24 hours of extraction to 3 X24 hours greatly increased. This event was caused by the higher time of the extraction which caused the cavity of the corn cavity and the content that was present gave a sharp increase. Corn that has been extracted into starch in each variety is influenced by several things including: (1) Differences in starch composition in various parts of corn kernels (endosperm, pericarp, institutions, epidermis, and tipcap) affect the extraction event. Starch extraction is the event of granule rupture until starch can be extracted. (2) The shape and size of the granules which varies according to the type and type of starch. (3) Gelatinization temperature is the temperature that causes the starch granules to swell until the granule matrix that encloses the starch becomes broken (separation of starch by binding to protein and fat). (4). The addition of chemicals that aim to bind or pull the bonds of protein and fat to separate it from starch [5]. Extraction process is the process of releasing bonds of fat and protein in starch granules. 


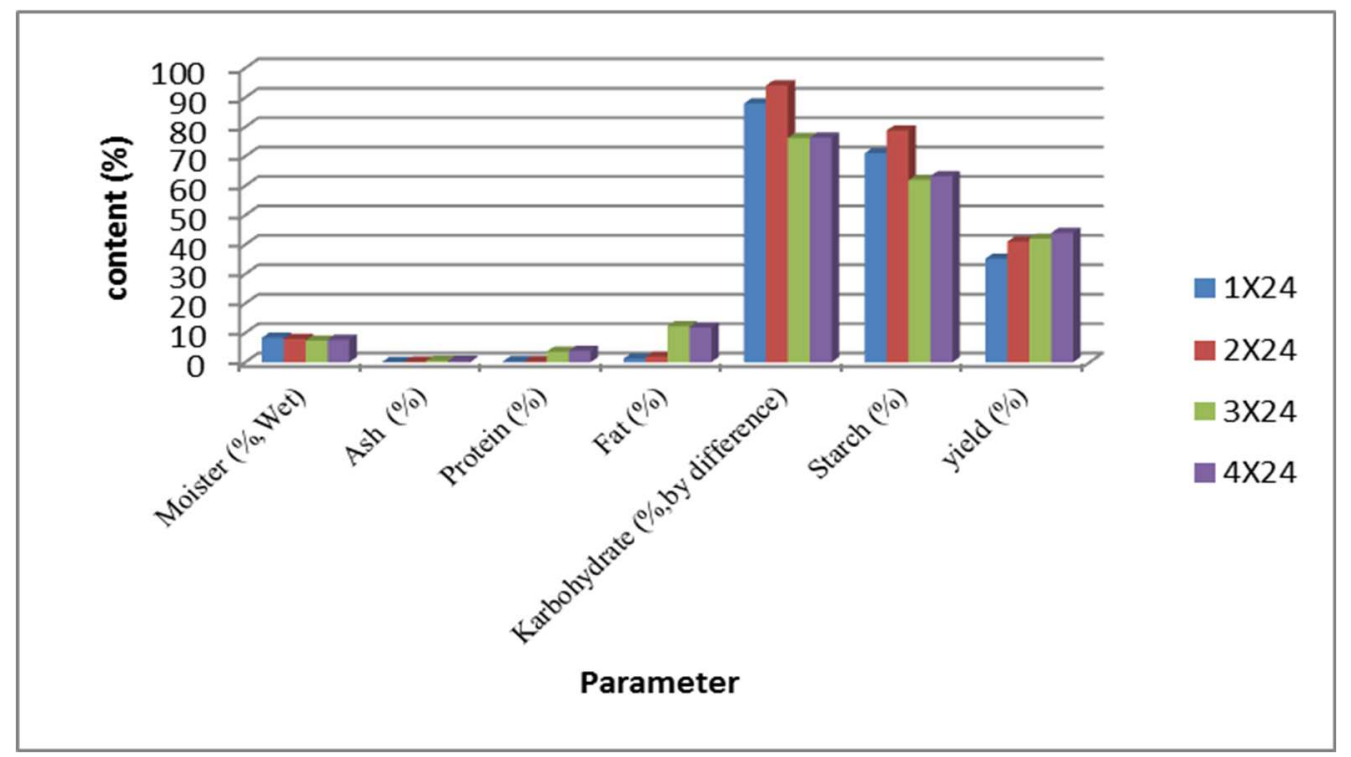

Figure 6. Parameter and Content Epidermis

\section{Conclusion}

The effect of time variation on starch extraction on the analysis of epidermis and yellow slurry skin parameters showed a decrease and an increase in each parameter analyzed. The resulting waste can be utilized in various industries especially the pharmaceutical food industry and the xylitol industry. 


\section{References}

[1] "Pembuatan Dekstrin Dari Tepung Tapioka Secara Enzimatik Dengan Pemanas Microwave Neliti." [Online]. Available: https://www.neliti.com/id/publications/141792/pembuatan-dekstrindari-tepung-tapioka-secara-enzimatik-dengan-pemanas-microwave. [Accessed: 17-Jan-2020].

[2] M. Suarni, I, Firmansyah, Aqil, "Diversity of Starch Quality of Several Corn Varieties.," 2013. [3] "Sni 01 2891-1992 cara uji makanan minuman." [Online]. Available: https://www.slideshare.net/Fitrijasmineandriani/sni-01-28911992-cara-uji-makanan-minuman.

[Accessed: 17-Jan-2020].

[4] "Sni 01-3920-1995 Jagung Acuan Organoleptik." [Online]. Available: https://www.scribd.com/document/347399477/Sni-01-3920-1995-Jagung-Acuan-Organoleptik.

[Accessed: 17-Jan-2020].

[5] "Starch, Third Edition: Chemistry and Technology - PDF Free Download." [Online]. Available: https://epdf.pub/starch-third-edition-chemistry-and-technology.html. [Accessed: 17-Jan2020].

[6] O. R. Fennema, Food chemistry. Marcel Dekker, 1996.

[7] M. Stasse-Wolthuis, "Influence of dietary fibre on cholesterol metabolism and colonic function in healthy subjects.," World review of nutrition and dietetics, vol. 36. pp. 100-140, 1981. 